\title{
EAD - Be Digital: The Rio Verde/Go Pilot Experiment, Preparations For Brasília And São Paulo And Projections For Brazil
}

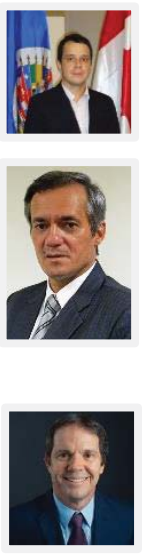

Moderator: ANDRÉ FELIPE SEIXAS TRINDADE

Communication Systems Engineer / ABRATEL / SET

Orientações aprovadas pelo GIRED para atuação da EAD

SEJA DIGITAL no processo de desligamento Speaker: José Alexandre Novaes Bicalho

Superintendente de Planejamento e Regulamentação da Anatel.

The Role, Effects and Interaction of the EAD with Brazilian

Broadcasters in the Digitalization Process

Speaker: Antônio Carlos Martelletto

President of the EAD - BE DIGITAL

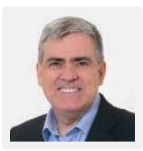

Planning \& Engineering - Impacts, Processes and Projects Speaker: Gunnar Bedicks

Chief Technology Officer (CTO) - EAD - BE DIGITAL

Measurements, Research and Communication: Metrification in Practice for the Industry

Speaker: Patrícia Abreu

Communication Director - EAD - BE DIGITAL

Interacting with Broadcasters in Digitalization: Definitions, Discussions and Collaborative Support Speaker: Paulo Ricardo Hermano Balduino CEO / Synthesis Consultoria - Director, Spectrum Planning / Brazilian Radio \& TV Broadcasters Association ABERT

How market entities can prepare for the impact of digitalization: how to dialog, follow up and direct their process

Speaker: André Felipe Seixas Trindade Engenheiro de Sistemas de Comunicação (Diretoria Corporativa) / ABRATEL / SET 


\section{Regulatory \& Norms}

\section{EAD - BE DIGITAL: THE RIO VERDE/GO PILOT EXPERIMENT, PREPARATIONS FOR BRASÍLIA AND SÃO PAULO AND PROJECTIONS FOR BRAZIL}

\section{Moderator: ANDRÉ FELIPE SEIXAS TRINDADE}

Communication Systems Engineer / ABRATEL / SET

An entity created at the behest of Anatel and consisting of the operators Algar Telecom, Telefónica - VIVO, Claro and Tim, BE DIGITAL is in charge of to putting into effect the migration of the analog terrestrial TV signal to digital. BE DIGITAL is currently operational, having undertaken the disconnection in Rio Verde (GO) and now focusing its attention on Brasília and Greater São Paulo. The work being done by the EAD follows the guidelines approved by the GIRED - the Group for the Implementation of the Redistribution and Digitalization Process for TV and RTV Channels - a consultative council consisting of representatives of Anatel, the MCTIC, the winning bidders and the national broadcasting associations that also oversees it. This panel will present to us the work undertaken by BE DIGITAL, clear up doubts about how to put into effect the rearrangement of channels, the campaigns that will be launched in locations to be disconnected by 2018 and in cities where there is early entry of LTE, surveys for measuring the percentage of converts, the distribution of kits containing the converters and the digital receiver antennae for families registered with the Single Social Programs Register. Even in locations where disconnection will not occur by 2018, BE DIGITAL will also be in charge of preventive and corrective actions to solve any interference arising from LTE, in addition to campaigns for fine-tuning the channels (if so required).

- Orientações aprovadas pelo GIRED para atuação da EAD SEJA DIGITAL no processo de desligamento

Speaker: José Alexandre Novaes Bicalho

Superintendente de Planejamento e Regulamentação da Anatel.

Serão apresentadas as principais orientações aprovadas pelo Colegiado do GIRED para a atuação da EAD, em especial nas campanhas de deviulgação de switch-off e ressintonia, pesquisas de aferição do percentual de convertidos e orientações sobre o remanejamento.

- The Role, Effects and Interaction of the EAD with Brazilian Broadcasters in the Digitalization Process

Speaker: Antônio Carlos Martelletto

President of the EAD - BE DIGITAL

- Planning \& Engineering - Impacts, Processes and Projects

Speaker: Gunnar Bedicks

Chief Technology Officer (CTO) - EAD - BE DIGITAL

- Measurements, Research and Communication: Metrification in Practice for the Industry

Speaker: Patrícia Abreu

Communication Director - EAD - BE DIGITAL 
- Interacting with Broadcasters in Digitalization: Definitions, Discussions and Collaborative Support

Speaker: Paulo Ricardo Hermano Balduino

CEO / Synthesis Consultoria - Director, Spectrum Planning / Brazilian Radio \& TV Broadcasters

Association ABERT

- How market entities can prepare for the impact of digitalization: how to dialog, follow up and direct their process

Speaker: André Felipe Seixas Trindade

Engenheiro de Sistemas de Comunicação (Diretoria Corporativa) / ABRATEL / SET

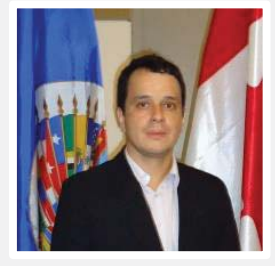

\section{ANDRÉ FELIPE SEIXAS TRINDADE}

consultant on regulatory and governmental affairs - ABRATEL. SET..

Andre is the consultant on regulatory and governmental affairs of the Abratel - The Brazilian Radio and Television Association - representing radio and television in Brazil and participating in the Inter American Telecommunications Commission (CITEL) as part of the Brazilian delegation, on issues involving policies, planning and spectrum utilization, the future of television programs and new technologies. He worked for Claro (network planning and quality - GSM and 3G networks) and began his work in the broadcasting, with 8 years' experience in those fields. He is a member of the Anatel Brazilian Communications Commission - CBC 2 and is a member of the Brazilian delegation that takes part in the meetings of the Permanent Consultative Committee II of the Inter American Telecommunications Commission - CITEL - the entity within the Organization of American States in charge of harmonizing spectrum use in the Americas. He is also a member of several Radio Communications Reporting Groups of Anatel - GRRs and was a member of the Consultative Council on Digital Radio to the Ministry of Communications. He is a speaker on issues involving broadcasting, and a full member of the GIRED - the Group for Implementing the TV and RTV Channel Redistribution and Digitalization process.

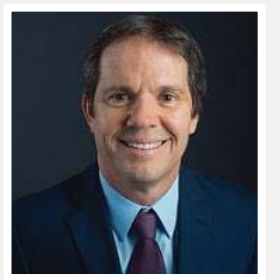

\section{ANTÔNIO CARLOS MARTELLETTO}

President - EAD

Holds a degree in Electrical Engineering/ Electronics from PUC-RJ, with a specialization in Telecommunications from UNICAMP. He has been an Executive Officer of the América Móvil group since 2008, having previously CTO at Vivax and having worked at companies like Globosat, Telebrás and Promon Engineering.

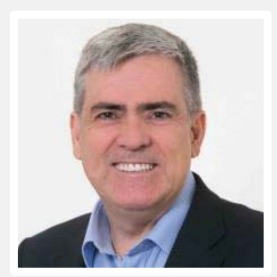

\section{Gunnar Bedicks}

COT at EAD. - Chief Scientist at the Digital TV Research Centre of the Universidade Presbiteriana Mackenzie

Gunnar Beddicks: CTO at EAD - Associação Administradora do Processo de Redistribuição e Digitalização de Canais de TV e RTV/ Chief Scientist at the Digital TV Research Centre of the Universidade Presbiteriana Mackenzie in Sao Paulo. Gunnar Bedicks is one of Brazil's most distinguished experts in developing, deploying and evangelizing for digital TV. In the last decade, he has visited 32 countries around the world to discuss their switch from analog to digital television. In 2013, President of Brazil Dilma Russef awarded Dr. Bedicks the highest honor in Brazilian diplomacy, the Medal of the Order of Rio Branco, for his achievements. Besides being Chief Scientist at the Digital TV Research Centre of the Universidade Presbiteriana Mackenzie in Sao Paulo, he teaches postgraduate, graduate and undergraduate courses in Digital Communications at the same university. He was one of the lead engineers for the testing and research that led the government of Brazil to adopt digital TV in 2004. His publications include more than a dozen scientific articles, and he has presented at technical conferences in Brazil, USA, Canada, Korea, Japan, China, Germany, France, Sweeden, Switzerland, Italy, Spain, South Africa, Botswana, Angola, Mozambique, Lesotho, Mauritus, Argentina, Chile, Colombia, Cuba, Costa Rica, Paraguay, Peru, Venezuela and Bolivia. Dr. Bedicks has more than 20 years 

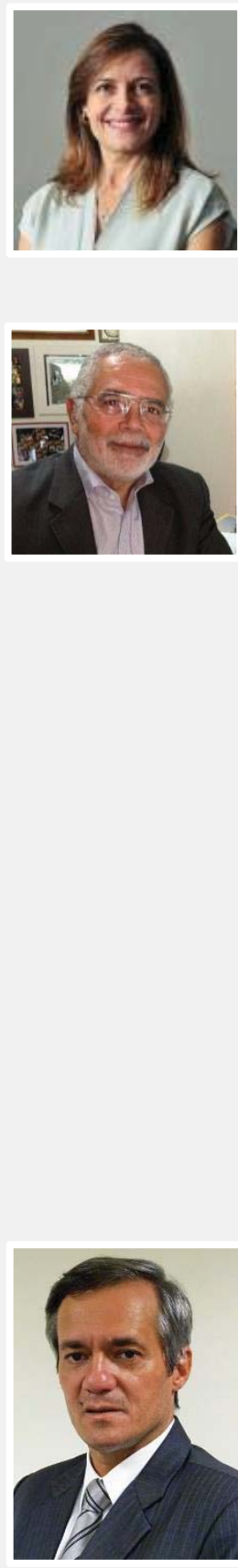

Planning and Regulations Superintendent - Anatel

He holds a Computer Science degree from the University of Brasília (UnB), and a Master's in Networks and Data Bases from the Federal University of Paraíba (UFPB). He worked at Telebrás, from 1998 until the creation of Anatel. He was involved in setting up the Agency's Committee on National Information Infrastructure (C-INI). He coordinated the Brazilian Commission on Communications - Internet Governance (CBC-13) and represented the Agency on the Internet Steering Committee in Brazil, in addition to representing Brazil on the Governmental Advisory Committee (GAC) of the ICANN and at the World Summit on the Information Society (WSIS) for Internet Governance-related issues. He was a member of the Working Group on Internet Governance (WGIG), having been indicated by the Secretary-General of the United Nations and by the Multi-stakeholder Advisory Group (MAG) of the Internet Governance Forum (IGF). He was an advisor to the president's office of Anatel and to the Board of Directors. Since 2013 he has been the Planning and Regulations Superintendent at Anatel.

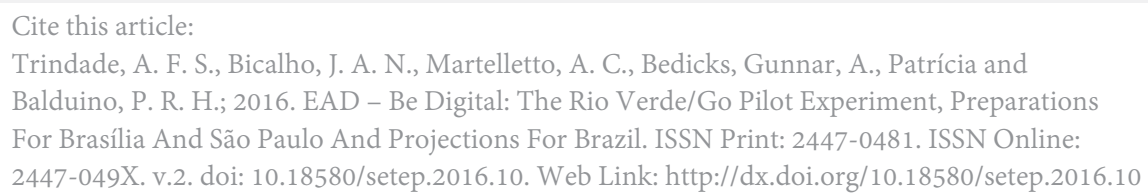

